http://doi.org/10.35784/iapgos.2826

\title{
INCREASING THE COST-EFFECTIVENESS OF IN VITRO RESEARCH THROUGH THE USE OF TITANIUM IN THE DEVICE FOR MEASURING THE ELECTRICAL PARAMETERS OF CELLS
}

\author{
Dawid Zarzeczny \\ Lublin University of Technology, Department of Electrical Engineering and Electrotechnologies, Lublin, Poland
}

Abstract. Currently, various methods are used to assess the biocompatibility of materials. After an in-depth and detailed review of the literature, the method used in the research was selected. As part of the experiments, a method based on the analysis of the values of electrical parameters of cell cultures measured in the presence of electrodes was used. The electrode is a structure made of a thin layer of metallization. It measures the change in resistance, impedance and capacity of a mixture of cells and the substance in which they are grown. The plate containing the electrode assembly is called the measurement matrix. Currently, commercially used test matrices are made of gold or platinum. However, their high price means that large-scale research is significantly limited. In order to increase the access to the widespread use of this method, it was decided that it was necessary to use cheaper materials, reducing the necessary costs of conducting experiments. Considering this, an attempt was made to use a different conductive material to build matrices compatible with the ECIS® Z-Theta measurement system. Their use would enable in vitro research on living cells. In the presented work, titanium was used as a material that may turn out to be an alternative to the materials currently used. Its application to the production of matrices will allow to study the influence of this metal on the behavior of cells.

Keywords: bioimpedance, titanium, MEMS, thin films

\section{ZWIĘKSZENIE EFEKTYWNOŚCI KOSZTOWEJ PROWADZENIA BADAŃ IN VITRO POPRZEZ ZASTOSOWANIE TYTANU W URZĄDZENIU DO POMIARU PARAMETRÓW ELEKTRYCZNYCH KOMÓREK}

\begin{abstract}
Streszczenie. Obecnie, do oceny biokompatybilności materiałów wykorzystywane sa różne metody. Po dogtębnym i szczegółowym przeglądzie literatury wybrano metodę, która wykorzystano podczas prac badawczych. W ramach przeprowadzonych eksperymentów wykorzystano metodę bazująca na analizie wartości parametrów elektrycznych kultur komórkowych, zmierzonych w obecności elektrod. Elektroda jest struktura wykonana w cienkiej warstwie metalizacji. Stuży do pomiaru zmiany wartości rezystancji, impedancji oraz pojemności mieszaniny złożonej z komórek $i$ substancji, $w$ której sa one hodowane. Plytka zawierajaca zestaw elektrod nazywana jest matryca pomiarowa. Aktualnie, komercyjnie stosowane matryce testowe wykonane sa ze złota lub platyny. Ich wysoka cena powoduje jednak, że prowadzenie badań na szeroka skale jest znaczaco ograniczone. Aby zwiększyć dostęp do powszechnego korzystania z tej metody zdecydowano, że koniecznym jest stosowanie tańszych materiałów, redukując niezbędne koszty prowadzenia eksperymentów. Zważywszy na to, podjęto próbe zastosowania innego materiału przewodzacego do budowy matryc kompatybilnych z systemem pomiarowym ECIS ${ }^{\circledR}$ Z-Theta. Ich użycie umożliwitoby prowadzenie badań nad komórkami żywmi in vitro. W przedstawionej pracy jako materiat, który może okazać się alternatywa dla materiałów wykorzystywanych obecnie wykorzystano tytan. Jego zastosowanie do wytworzenia matryc pozwoli zbadać wplyw tego metalu na zachowanie komórek.
\end{abstract}

Slowa kluczowe: bioimpedancja, tytan, MEMS, cienkie warstwy

\section{Purpose of the research}

The aim of the research work was to develop a device that would allow conducting medical and biological experiments with a lower financial outlay. The main requirement when designing similar devices is that the materials used, in addition to such properties as corrosion and wear resistance, non-toxicity and appropriate mechanical properties, are characterized by high biocompatibility $[9,12,13,30]$.

Table 1. List of prices of target materials

\begin{tabular}{|c|c|c|c|c|}
\hline Material & Symbol & $\begin{array}{c}\text { Target diameter } \\
{[\mathrm{cm}]}\end{array}$ & $\begin{array}{c}\text { Target thickness } \\
{[\mathrm{cm}]}\end{array}$ & $\begin{array}{c}\text { Target price } \\
{[\text { Euro] }}\end{array}$ \\
\hline Gold & $\mathrm{Au}$ & 5.08 & 0.1588 & 3072.00 \\
\hline Platinum & $\mathrm{Pt}$ & 5.08 & 0.1588 & 3294.72 \\
\hline Titanium & $\mathrm{Ti}$ & 5.08 & 0.3175 & 116.10 \\
\hline
\end{tabular}

A wide range of available raw materials, with a different degree of biocompatibility, allows the selection of such a material that shows a favorable response in a given biological environment, while fulfilling the required function [1, 21]. Usually, noble metals, in particular gold or platinum, are used to build devices that come into contact with a living organism. However, the high cost limits their use in, for example, disposable devices. Looking for an alternative to expensive materials, it was decided to use titanium which, like gold and platinum, is among the non-reactive metals that have little or no effect on the cells surrounding them $[5,11,25]$. Titanium is relatively inert and has good corrosion resistance, which is due to the presence of oxides on its surface. It also has very good mechanical properties. It has low thermal conductivity, relatively low density, low modulus of elasticity and high reactivity. These features are extremely important when used in sensitive areas of the human body $[19,25]$.

\section{Research method}

When assessing the possibilities of using a given material in medical applications, it is necessary to conduct a number of biological experiments. The test carried out under strictly defined conditions is to determine whether the properties of the material are sufficient and meet the requirements. Most often, such verification is aimed at finding out the regularities governing a specific biological system in various situations. The observation of cellular behavior changing over time or under the influence of external factors provides a lot of important information. It enables, among others clarification of the toxicological profile of the test substance [17]. In this work, the method of measuring cell impedance in real time in vitro was used to determine the potential possibility of using titanium in a safe way for the tested cells [1, 3, 10, 22, 27, 29]. The methodology of conducting in vitro tests is described in the ISO 10993-5 standard - "In vitro cytotoxicity tests" $[16,20]$.

Live biological cell impedance measurements are marker-free, non-invasive methods of quantitative analysis. They are used to assess the condition of cells, their biological activity and reactions related to the influence of external factors and chemicals [32]. During the measurement, the signal is supplied to the system in the form of alternating current with a current of less than $1 \mathrm{~mA}$ [4] $\left(4 \mathrm{~mA} / \mathrm{cm}^{2}\right)$, the frequency value of which ranges from $10 \mathrm{~Hz}$ to $64 \mathrm{kHz}$ [15]. At frequencies below $2 \mathrm{kHz}$, a significant amount of current flows between the intercellular spaces, providing information about cell adherence. The use of a relatively high frequency, above $40 \mathrm{kHz}$, causes a direct current flow through cell membranes $[2,4,15,18,28]$.

Commercial software of the Applied Biophysics measuring system using special mathematical transformations, generates results and plots the characteristics of impedance change. Each 
value read is plotted as a point in ohms $(\Omega)$ or nanofarads $(\mathrm{nF})$ per unit time $[2,28]$. The impedance value is at its highest when the cell culture is at its maximum confluence. The obtained resistance value corresponds to the resistance of the current flowing through the tested cell, while the capacitance causes the polarization of the separation of electrons in the isolated layer of the cell membrane. The duration of the experiment is set by the user and may last from a few seconds to several days. The differences between the measurement values are submitted for analysis, which determines the influence of individual factors and other external stimuli on the properties of the tested cells [7, 8, 31, 34].

The basic process of increasing the number of cells by multiplying and dividing is proliferation. It increases the degree of coverage of the electrode with the non-conductive cell membrane. This results in a significant increase in the measured impedance. Monitoring the process of cell proliferation using the bioimpedance measurement method is not a direct method of counting the number of cells, but a registration of changes resulting from a change in the coverage of the measuring electrode area. There is a close relationship between the number of cells and the normalized impedance value [24, 31, 32].

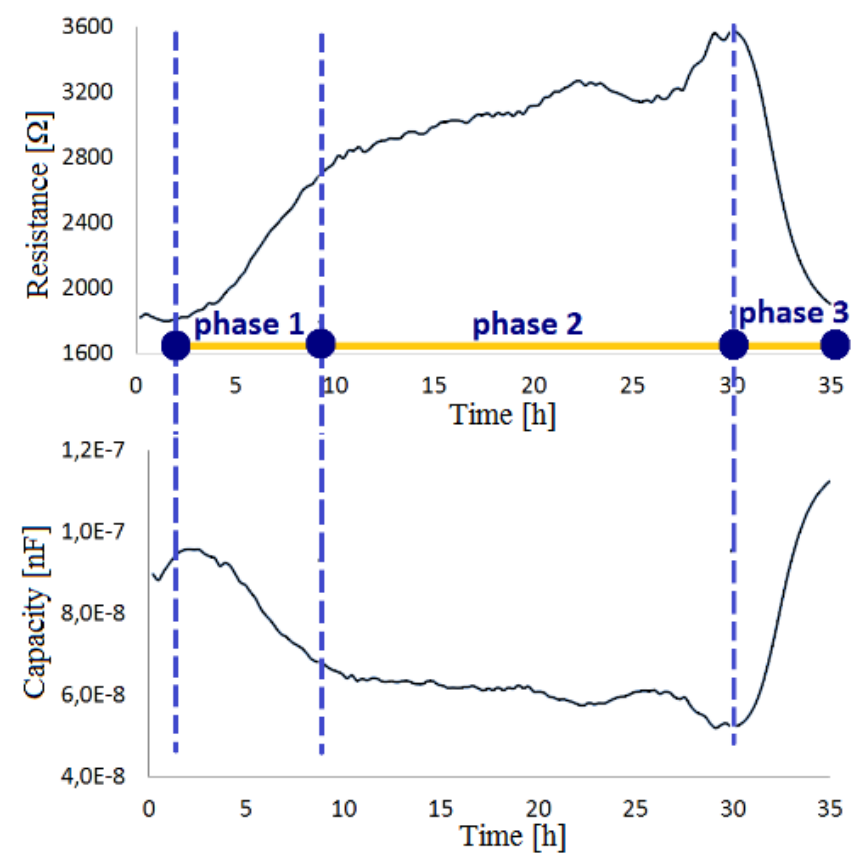

Fig. 1. The expected nature of changes in the measured resistance for $4 \mathrm{kHz}$ and capacity for $64 \mathrm{kHz}$ (measurements made with the use of commercial matrices with gold electrodes) [6]

\section{Experiment}

Based on the Applied Biophysics measurement system and commercial test matrices, a proprietary device was constructed to check the possibility of using conductive materials other than commercially used gold. The experiment begins with the preparation of a test plate on the surface of which a set of thinlayer detection electrodes is made [31]. The electrodes are defined as very small holes in the dielectric layer revealing the metallization deposited on the biocompatible substrate. Cells are grown on their surface. Commercially available standard backing plates used during measurements are made of biocompatible plastics, i.e. Lexan polycarbonate or polyethylene terephthalate PET [23]. The arrangement and shape of the electrodes on the measuring plate have a significant impact on the data obtained during the measurement. The most common are 8-well plates, which contain round electrodes or electrodes with a comb structure. The diameter of round electrodes varies from $250 \mu \mathrm{m}$ to $350 \mu \mathrm{m}$. The surface area of the comb structure electrodes ranges from $1.96 \mathrm{~mm}^{2}$ to $3.92 \mathrm{~mm}^{2}$. The number and shape of electrodes for a single well affects the number of cells that can be tested at one time. Single-electrode plates are used when the cell populations are small. The small total area of the electrodes causes all current to flow through the cell layer. This makes it possible to obtain a relatively high electric field with a moderately low alternating current. There is a possibility of full or partial electroporation and observation of uncontrolled morphological changes in small groups of cells $(<100)$. Multi-electrode plates allow you to analyze the properties of larger groups of cells, providing an estimate of the morphological response of a large population $(>1000)[2,23]$. Above each pair of electrodes there is a special container attached with a biocompatible silicone. Tested cell cultures are applied to its interior. In order to provide the necessary nutrients for the culture, the test cells are placed in a medium. The set thus completed is placed in an incubator that provides the cells with appropriate environmental conditions $[23,28]$.

\section{Production technology}

The process of producing matrices for measuring cell impedance began with formulating the requirements that should be met. The aim of the work was to create structures enabling in vitro tests with the use of cell cultures at acceptable costs of conducting experiments. Using the method of analyzing the electrical parameters of cell culture by measuring their impedance, it was necessary to determine the properties of the test plate. Currently used matrices are made entirely of biocompatible materials. As a base material, Lexan or PET that is harmless to cells and allows them to grow on its surface is used. The electrodes, on the other hand, are made of gold or platinum metallization. In addition, there is a layer of biocompatible dielectric on their surface. The cells are in contact with the electrodes thanks to the holes created on its surface. While the use of the abovementioned substrates does not generate high costs, the abovementioned metals and the dielectric layer consume a significant part of the expenditure. In order to limit the means necessary to conduct research, it was decided to use different conductive materials than those used so far. In addition, the dielectric layer was removed, so that the cells would have direct contact with the material.

The next stage of work was the selection of the optimal shape of the electrodes, which were to be placed on the target plate for measuring cell impedance. Based on the currently used configurations, it was decided that comb structures would be the best choice. Following the example of commercial 8W10E plates, a mask with eight electrodes placed on a single substrate was designed. Thanks to the same pin arrangement as in the case of standard boards supplied by the manufacturer of the measuring equipment, the set can be adapted to conduct experiments in the ECIS $^{\circledR}$ Z-Theta system apparatus. After a series of experiments, comb capacitors with dimensions of $200 \mu \mathrm{m} \times 200 \mu \mathrm{m}$ were selected for the next stages of development works on matrices for measuring cell impedance. The structures produced were the result of using the lift-on method, with the use of positive photosensitive emulsion - Positiv 20. The patterns were obtained with the use of the universal developer for photolists and positive plates AGT - 087 or sodium metasilicate pentahydrate. Sodium persulfate B327 was used to etch the metallization layers.

After selecting the shape of the electrodes and designing the technological masks, the next stage of the work was to select the appropriate substrate on which the target structures were to be produced. The main requirement determining the selection was that the material should not adversely affect and be indifferent to living organisms. In addition to high biocompatibility, necessary when conducting research with the use of living organisms, the base material should be resistant to chemical compounds used during technological processes and mechanical resistance, guaranteeing the appropriate strength of the matrix during its use. In the end, polycarbonate turned out to be a substrate that met all the assumptions and allowed it to be used freely. The $2 \mathrm{~mm}$ thick transparent plates kept their original shape. Moreover, they did not react chemically with any of the substances used in the photolithography process $[7,33]$. 
The material from which the measuring electrodes were made was titanium (purity $99.995 \%$ ). The first deposited layer was $\sim 40 \mathrm{~nm}$ thick (Fig. 2A). After measuring the resistance of the leads, it turned out that the value is too high (larger than $20 \mathrm{k} \Omega$ ) and it will not be possible to measure the electrical parameters of the cell culture. The test station was unable to detect the test plate inserted in its holders. Therefore, in the subsequent sputtering process, a layer of titanium with a thickness of $\sim 400 \mathrm{~nm}$ was deposited (Fig. 2B). The measured value of the resistance of the leads ranged from $\sim 960 \Omega$ to almost $18 \mathrm{k} \Omega$. However, these were acceptable values, allowing the measurements of resistance, impedance and capacitance to be carried out.

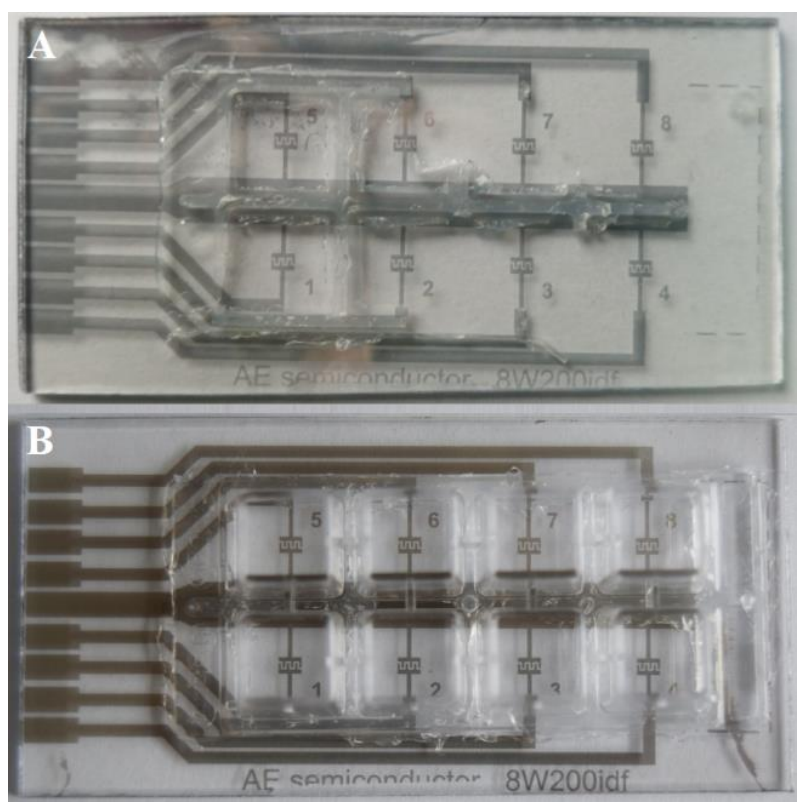

Fig. 2. Plates with titanium electrodes with a metallization layer thickness of $40 \mathrm{~nm}$ (A) and $400 \mathrm{~nm}(B)$

After the deposition of the metallization layer and photolithography have been carried out, the next step is to prepare the finished plate for testing. For this purpose, special containers are placed above the electrodes, into which the tested organic compounds are introduced. It is attached using a special biocompatible silicone. To obtain adequate sterility, plates with approved wells are exposed to UV irradiation for approx. 15 minutes, which is bactericidal. The set prepared in this way is used for cell culture and research [33].

All biological experiments were carried out at the Chair and Department of Human Physiology of the Medical University of Lublin. The first step is to apply $600 \mu$ of the culture medium to check the tightness of the wells. Then, the matrices are fixed in the measuring station located in a special incubator. After stabilization of the conditions inside the chamber, the electric parameters of the dies are calibrated. The next step is to place cell cultures inside the wells [24]. The final step is to provide cells with the environmental conditions necessary for their development by regulating temperature, oxygen and/or carbon dioxide concentration. After their stabilization, the measurement of electrical parameters begins.

The optimal frequency values at which the results are interpreted are $4 \mathrm{kHz}$ for resistance, $16 \mathrm{kHz}$ for impedance and $64 \mathrm{kHz}$ for capacitance $[15,18,26]$. All obtained data are presented in a normalized form. The obtained results are presented in the graphs in a normalized form, which allows to observe the changes in the value and compare the trend of changes without the influence of the resistance of the leads. The work uses the min - max normalization expressed by the formula [14]:

$$
x^{\prime}=\frac{x-x_{\min }}{x_{\max }-x_{\min }}
$$

where $x^{\prime}$ is the normalized value within the range from 0 to 1 , while $x, x_{\min }, x_{\max }$ mean the normalized value and the smallest and largest value of the normalized interval, respectively.
The next stage of the work was to measure the electrical parameters of the cell culture. Cell lines from the American Type Culture Collection (ATCC) were used in the laboratory studies. All the cells used were used due to their current availability at the time when it was possible to use the measuring equipment of the Department of Human Physiology of the Medical University of Lublin. The mouse fibroblast L 929 cell line and the simian VERO cell line were used in the experiments. The obtained results are presented in the graphs in a normalized form, which allows to observe the changes in the value and compare their tendency of change without the influence of the resistance of the leads.

\section{Measurement results}

The first cells tested were murine fibroblasts designated as L929. During the experiment, results were obtained from all wells containing cultured cells. However, the cell cycle did not enter the apoptotic phase. The software of the measurement system allows you to monitor changes in real time, displaying the measured values in the form of generated graphs. During the experiment, the displayed characteristics curves were straight lines, where no significant changes could be observed (Fig. 3). The supervisor of the experiment stated that this was due to a lack of cellular activity. Therefore, the measurement of electrical parameters was interrupted and only the proliferation stage was recorded.

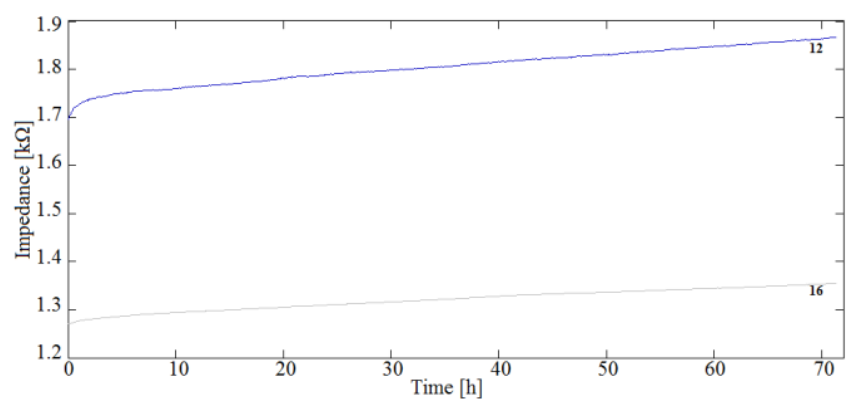

Fig. 3. Measured impedance of L 929 cell culture grown on a plate with titanium electrodes, for the $16 \mathrm{kHz}$ signal, for wells 12 and 16 (graph from the ECIS Z-Theto system

During the preparation of the results and their normalization, it was noticed that the nature of the changes showed an increasing tendency, and the invisible changes resulted from slight differences between the recorded changes and the measured value. The change of several hundred ohms against the background of several kiloohms required the normalization of the results in order to be noticed. The general trend of changes recorded in the wells allows for the conclusion that there was cell proliferation, which is visible in the change of the measured parameters. A linear change of the measured parameters can be observed, which allows to conclude that the cultured cells had no problems with multiplication and spreading over the electrode surface. By its action, titanium did not disrupt the cell cycle of mouse fibroblasts. Throughout the measurement period, an increase in resistance (Fig. 4) and a decrease in capacitance (Fig. 5) resulting from the continuous multiplication of cells are observed.

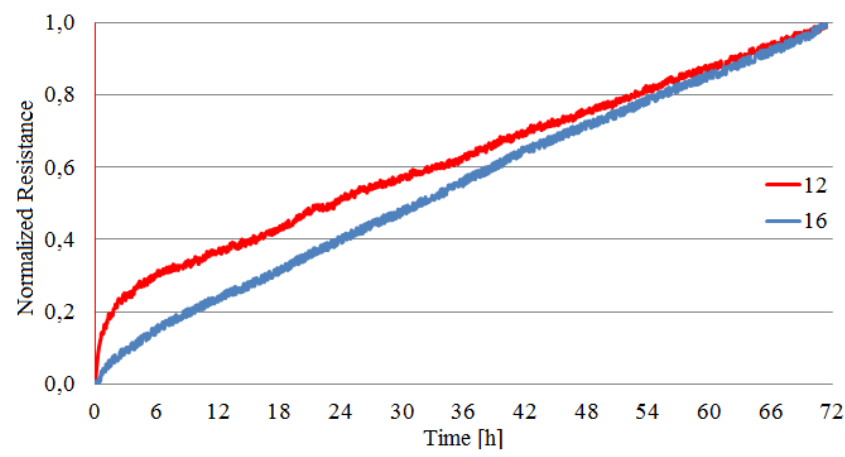

Fig. 4. Normalized resistance of L 929 cell culture carried out on a plate with titanium electrodes, for a signal of $4 \mathrm{kHz}$, for wells 12 and 16 


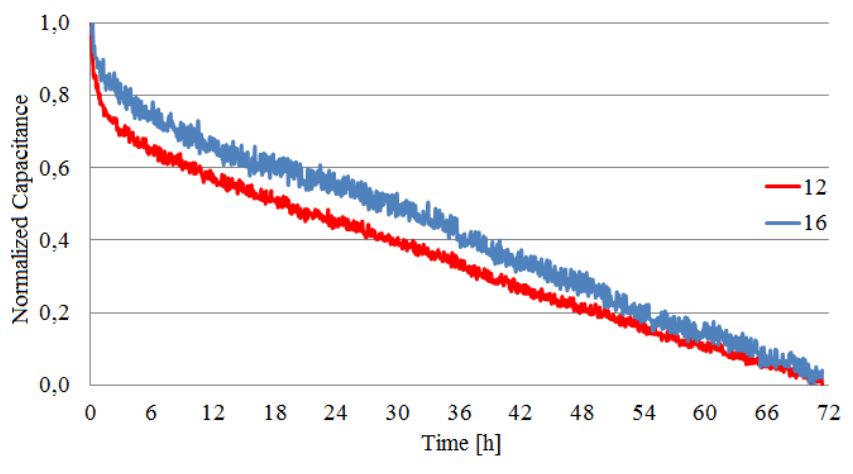

Fig. 5. Normalized capacity of the L 929 cell culture carried out on a plate with titanium electrodes, for a signal of $64 \mathrm{kHz}$, for wells 12 and 16

The fact that the titanium made it possible to register changes despite the high resistance of the leads is not changing. The measurement matrices showed slight changes in the resistance in relation to the high resistance of the lead paths. Based on the obtained data, it can be concluded that measuring arrays with titanium electrodes can be used for in vitro research on L929 cells.

Successive arrays with titanium electrodes were used to measure the electrical parameters of the VERO monkey cell culture (Fig. 6). In order to better notice the changes occurring, also in this case the normalization of the measured values was applied.

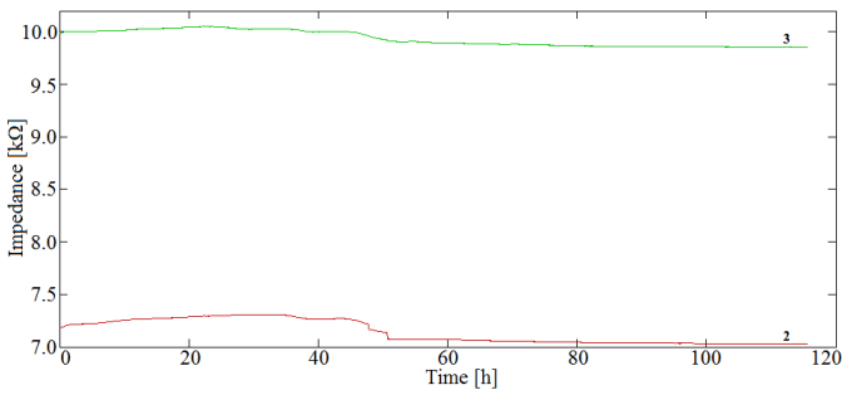

Fig. 6. Measured impedance of VERO cell culture grown on a plate with titanium electrodes, for the $16 \mathrm{kHz}$ signal, for wells 2 and 3 (graph from the ECIS Z-Theta system)

Changes in the parameters value, despite the initial instability, tend to change in time. The cultivation was carried out for over 115 hours, but the most noticeable changes are visible up to 48 hours of measurements. This has been shown in the charts showing the normalized resistance and capacitance.

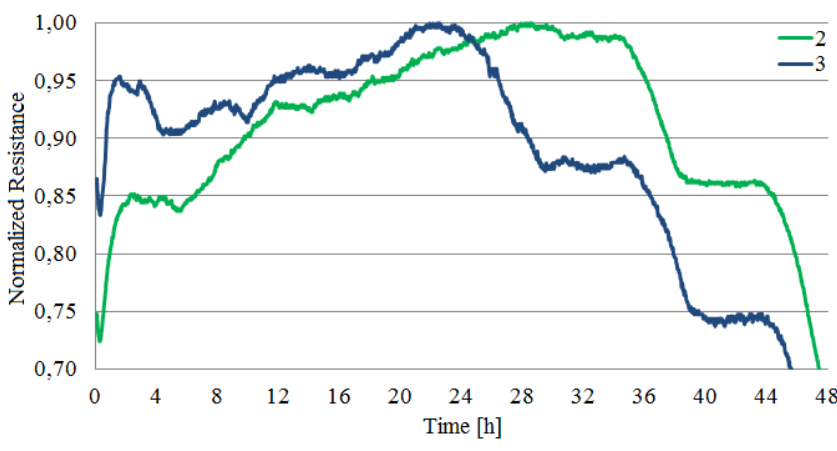

Fig. 7. Normalized resistance of VERO cell culture carried out on a plate with titanium electrodes, for a $4 \mathrm{kHz}$ signal, for wells 2 and 3

By limiting the measurement period to 48 hours, it is possible to observe all the changes that have occurred. All steps of the cell life cycle can be observed. After the initial fluctuation of the resistance (Fig. 7), its value increases. These changes indicate the proliferation and migration of cells over the surface of the measuring electrodes. Thereafter, growth is inhibited, which indicates that the cell culture is completely confluent. Cells there are on the entire surface of the bottom of the well and cannot develop further. The last stage of a cell's life is apoptosis. The cells increase in volume and lose their adhesion to the electrode surface. This causes the resistance value to drop.

The results of the capacitance measurements carried out at a frequency of $64 \mathrm{kHz}$ are characterized by large fluctuations. The results of measurements at a frequency of $16 \mathrm{kHz}$ show changes more clearly (Fig. 8). The nature of the changes tends to increase, which is not as expected. However, after consultation with researchers from the Medical University of Lublin, information was obtained that such changes were acceptable. Nevertheless, the answer to the question why the measured capacity value has increased belongs to in vitro research specialists. From an engineering point of view, the produced matrices made it possible to cultivate two types of cells and measure their electrical parameters.

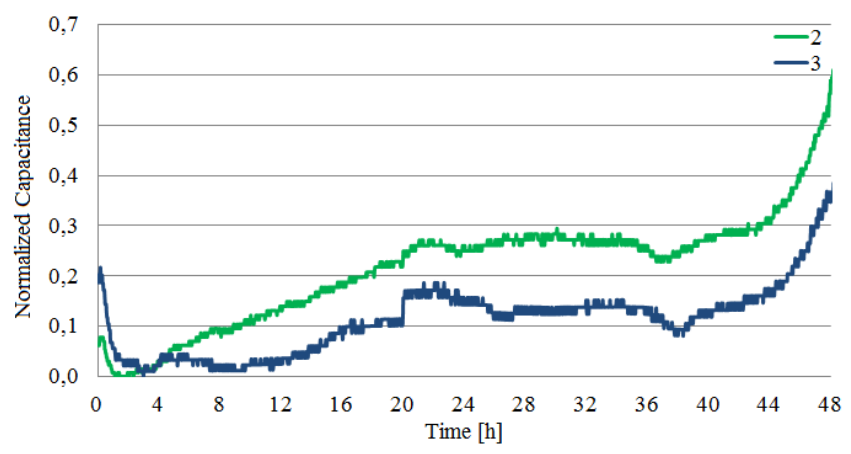

Fig. 8. Normalized capacity of the VERO cell culture carried out on a plate with titanium electrodes, for a $16 \mathrm{kHz}$ signal, for wells 2 and 3

\section{Conclusions}

The article presents the research results obtained with the use of measuring arrays with titanium electrodes. Two types of cells were used, mouse fibroblast L 929 cell line and the simian VERO cell line. In both cases, cell growth was observed on the surface of the measuring arrays. Titanium had no negative effect on the tested biological objects and made it possible for them to grow in his presence. The presented test results confirm the effectiveness of the use of arrays with titanium electrodes for in vitro testing of cells. Nevertheless, there is a need for further research.

In the presented experiment, animal and human cells were used successfully. It allows to argue that it is possible to make arrays from a material other than gold or platinum to conduct research on various types of cells. At the same time, this reduces the costs associated with conducting in vitro experiments.

\section{References}

[1] Ananth H., Kundapur V., Mohammed H. S., Anand M., Amarnath G. S., Mankar S.: A review on biomaterials in dental implantology. International Journal of Biomedical Science 11(3), 2015, 113-120.

[2] Applied BioPhysics, Inc., Product Guide,

[https://www.biophysics.com/whatIsECIS.php] (available: 26.11.2021).

[3] Gangadoo S., Chapman J.: Emerging biomaterials and strategies for medical applications: A review. Materials Technology 30, 2015, B3-B7 [http://doi.org/10.1179/1753555714Y.0000000206].

[4] Giaever I., Keese C. R.: Electric Cell-Substrate Impedance Sensing and Cancer Metastasis. Springer 17, 2012, 1-19 [http://doi.org/10.1007/978-94-007-49276_1].

[5] Jiang G.: Design challenges of implantable pressure monitoring system. Frontiers in Neuroscience 4, 2010, 1-4 [http://doi.org/10.3389/neuro.20.002.2010].

[6] Kociubiński A., Zarzeczny D., Prendecka M., Pigoń D., Małecka-Massalska T.: Nichrome Capacitors on Polycarbonate Substrate for Monitoring Cell Culture Using Impedance Sensing Technique. Archives of Metallurgy and Materials 65 , 2020, 493-496 [http://doi.org/10.24425/amm.2020.131752].

[7] Kociubiński A., Zarzeczny D., Szypulski M.: Kondensatory grzebieniowe $\mathrm{z}$ miedzi do monitorowania funkcji życiowych komórek hodowlanych. Przegląd Elektrotechniczny 1, 2018, 61-63 [http://doi.org/10.15199/48.2018.09.15]. 
[8] Kociubiński A., Zarzeczny D.: Nickel comb capacitors for real-time monitoring of cancer cell cultures. Przegląd Elektrotechniczny 9, 2020, 149-152 [http://doi.org/10.15199/48.2020.09.31].

[9] Kohane D. S., Langer R.: Biocompatibility and drug delivery systems. Chemical Science 1, 2010, 441-446 [http://doi.org/10.1039/c0sc00203h].

[10] Langer R., Tirrell D. A.: Designing materials for biology and medicine. Nature 428, 2004, 487-492 [http://doi.org/10.1038/nature02388].

[11] Meng E., Sheybani R.: Insight: implantable medical devices. Lab on a Chip 14, 2014, 3233-3240 [http://doi.org/10.1039/C4LC00127C].

[12] Menzies K. L., Jones L.: The Impact of Contact Angle on the Biocompatibility of Biomaterials. Optometry and Vision Science 87, 2010, 387-399 [http://doi.org/10.1097/OPX.0b013e3181da863e].

[13] Onuki Y., Bhardwaj U., Papadimitrakopoulos F., Burgess D. J.: A review of the biocompatibility of implantable devices: Current challenges to overcome foreign body response. Journal of Diabetes Science and Technology 2, 2008, 1003-1015 [http://doi.org/10.1177/193229680800200610].

[14] Patro S. G. K., Sahu K. K.: Normalization: A Preprocessing Stage. IARJSET 2(3), 2015, 20-22 [http://doi.org/10.17148/iarjset.2015.2305].

[15] Pennington M. R., Walle G. R. Van de, Smith G. A.: Electric Cell-Substrate Impedance Sensing To Monitor Viral Growth and Study Cellular Responses to Infection with Alphaherpesviruses in Real Time. MSphere 2, 2017, 1-12 [http://doi.org/10.1128/mSphere.00039-17].

[16] PN-EN ISO 10993-1:2010 Biologiczna ocena wyrobów medycznych, 2015, http://www.urpl.gov.pl/en/node/267 (available:26.11.2021).

[17] Porta M.: A Dictionary of Epidemiology (6 ed.). Oxford University Press, Oxford 2014 [http://doi.org/10.1093/acref/9780199976720.001.0001].

[18] Prendecka M., Małecka-Massalska T., Mlak R., Magdalena J., Osińska-Jaroszuk M., Jakubiak-Hulicz M., Leibold C., Bieser A., Wójcik W.: Effect of exopolysaccharide from Ganoderma applanatum on the electrical properties of mouse fibroblast cells line L929 culture using an electric cel-substrate impedance sensing (ECIS). Annals of Agricultural and Environmental Medicine 23, 2016, 293-297 [http://doi.org/10.5604/12321966.1203891].

[19] Rack H. J., Qazi J. I.: Titanium alloys for biomedical applications. Materials Science and Engineering C 26(8), 2006, 1269-1277 [http://doi.org/10.1016/j.msec.2005.08.032]

[20] Rozporządzenie Ministra Zdrowia z dnia 16 lutego 2016 r. w sprawie szczegółowych wymagań dotyczących planowania, prowadzenia, monitorowania i dokumentowania badania klinicznego wyrobu medycznego (Dz. U. z 2016 r. poz. 209)

[21] Saini M.: Implant biomaterials: A comprehensive review. World Journal of Clinical Cases 3, 2015, 52-57 [http://doi.org/10.12998/wjcc.v3.i1.52].

[22] Scholten K., Meng E.: Materials for microfabricated implantable devices: a review. Lab on a Chip 15, 2015, 4256-4272 [http://doi.org/10.1039/C5LC00809C].

[23] Stolwijk J. A., Matrougui K., Renken C. W., Trebak M.: Impedance analysis of GPCR-mediated changes in endothelial barrier function: overview and fundamental considerations for stable and reproducible measurements. Pflügers Archiv - European Journal of Physiology 467, 2015, 2193-2218 [http://doi.org/10.1007/s00424-014-1674-0].
[24] Szulcek R., Bogaard H. J., van Nieuw Amerongen G. P.: Electric Cell-substrate Impedance Sensing for the Quantification of Endothelial Proliferation, Barrier Function, and Motility. Journal of Visualized Experiments 85, 2014, 1-12 [http://doi.org/10.3791/51300].

[25] Veiga C., Davim J. P., Loureiro A. J. R.: Properties and applications of titanium alloys. Reviews on Advanced Materials Science 32, 2012, 133-148.

[26] Voiculescu I., Li F., Nordin A. N.: Impedance Spectroscopy of Adherent Mammalian Cell Culture for Biochemical Applications: A Review. IEEE Sensors Journal 21, 2021, 5612-5627 [http://doi.org/10.1109/JSEN.2020.3041708].

[27] Walkowiak B.: Biomedyczne skutki kontaktu tkanki z implantem. Inżynieria Biomateriałów 7, 2004, 38-42.

[28] Wegener J., Keese C. R., Giaever I.: Electric cell-substrate impedance sensing (ECIS) as a noninvasive means to monitor the kinetics of cell spreading to artificial surfaces. Experimental Cell Research 259, 2000, 158-166 [http://doi.org/10.1006/excr.2000.4919].

[29] Wesolowski R. A., Wesolowski A. P., Petrova R. S.: Biomaterials. In: The World of Materials. Springer International Publishing, Cham 2020, 75-78 [http://doi.org/10.1007/978-3-030-17847-5_12].

[30] Williams D. F.: On the mechanisms of biocompatibility. Biomaterials 29, 2008 , 2941-2953 [http://doi.org/10.1016/j.biomaterials.2008.04.023].

[31] Xiao C., Luong J. H. T.: On-line monitoring of cell growth and cytotoxicity using electric cell-substrate impedance sensing (ECIS). Biotechnology Progress 19, 2003, 1000-1005 [http://doi.org/10.1021/bp025733x].

[32] Xu Y., Xie X., Duan Y., Wang L., Cheng Z., Cheng J.: A review of impedance measurements of whole cells. Biosensors and Bioelectronics 77, 2016, 824-836 [http://doi.org/10.1016/j.bios.2015.10.027].

[33] Zarzeczny D.: Projekt i technologia kondensatorów grzebieniowych do monitorowania hodowli komórek. In: Problemy Współczesnej Inżynierii Wybrane zagadnienia elektroniki i inżynierii biomedycznej. Politechnika Lubelska, Lublin, 2017, 155-168, [http://bc.pollub.pl/Content/13165/PDF/sneie.pdf] (available: 26.11.2021).

[34] Zarzeczny D. A.: Thin film capacitors made of various metals for impedance sensing technique. Proc. SPIE 11176, 2019, 1117654 [http://doi.org/10.1117/12.2536787].

\section{M.Sc. Eng. Dawid Zarzeczny}

e-mail: d.zarzeczny@pollub.pl

He graduated in Mechatronics at the Lublin University of Technology. Ph.D. student at the Lublin University of Technology. Since 2021, he has been employed as a didactic and research worker at the Lublin University of Technology. His research area focuses on microeletronics, semiconductor technology, plasma technology and biomedical engineering.

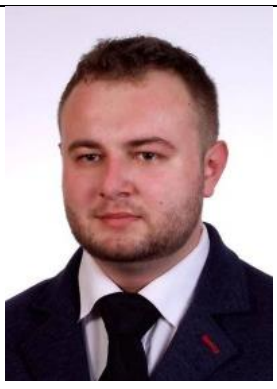

http://orcid.org/0000-0003-2029-9962

otrzymano/received: 19.11.2021 przyjęto do druku/accepted: 15.12.2021 